\title{
Workaholism - psychological and social determinants of work addiction
}

\author{
Pracoholizm - psychologiczne i społeczne uwarunkowania uzależnienia od pracy
}

\author{
Ewelina Soroka ABDEF, https://orcid.org/0000-0001-6909-2749, Aleksandra Iwanicka ABDEF,
} https://orcid.org/: 0000-0002-8603-4732, Marcin OlajosSy DE, https://orcid.org/0000-0002-1001-3185

II Department of Psychiatry and Psychiatric Rehabilitation, Medical University of Lublin

\begin{abstract}
Introduction: Workaholism as a psychological and social phenomenon is the object of only a few empirical studies. Despite the fact that the phenomenon of addiction to work was not specified in the ICD-10 or DSM-5 Classifications, the authors of this paper have decided that it is worth considering its preconditions.

Materials and method: Based on the review of the available literature, the topic of work addiction was discussed and the main determinants of workaholism and the so-called workaholic personality were presented.

Results: The paper presents the author's theoretical proposition of workaholism notion which postulates the existence of a form of addiction to work, which has its source in personality and motivation.

Conclusions: Undoubtedly, workaholism is addictive, but only obsessive-compulsive components may not be sufficient to determine its nature. Workaholism adopts a three-dimensional structure including behavioral, cognitive and affective aspects. Further research on this issue is needed.
\end{abstract}

Keywords: workaholism, work addiction, workaholic personality, motivation

\section{Streszczenie}

Wstęp: Pracoholizm jako zjawisko psychologiczne i społeczne jest obiektem niewielu badań empirycznych. Pomimo, iż nie zostało ono wyszczególnione ani w klasyfikacji ICD-10, ani DSM-5, autorzy pracy uznali, że warto przyjrzeć się jego uwarunkowaniom.

Materiał i metoda: Na podstawie przeglądu dostępnego piśmiennictwa przybliżono tematykę uzależnienia od pracy i opisano główne determinanty kształtujące pracoholizm i tzw. osobowość pracoholiczną.

Wyniki: W pracy przedstawiono autorską propozycję teoretyczną pracoholizmu, która postuluje istnienie formy uzależnienia od pracy, mającej swoje źródło w osobowości i motywacji.

Konkluzje: Niewątpliwie pracoholizm ma charakter uzależnienia, lecz same komponenty obsesyjno-kompulsyjne mogą okazać się niewystarczające do określenia jego natury. Zjawisko to przyjmuje strukturę trójwymiarową obejmującą aspekty behawioralne, poznawcze i afektywne. Niezbędne są dalsze badania nad zagadnieniem.

Słowa kluczowe: pracoholizm, uzależnienie od pracy, osobowość pracoholiczna, motywacja

"People are in a hurry at work, that's why they do it carelessly; they are in a hurry to use life, that's why they don't feel its taste; they are in a hurry to rest, so they can't relax."

\section{A. Kępiński Rhythm of life}

\section{Introduction and the aim of the study}

The modern world imposes a certain existential rush, in the age of computerization, innovation and ever newer amenities, the tendency to chase success is ubiquitous, and workaholism may arise on this ground. The phenomenon of workaholism is mainly dealt with by psychologists, and its consequences are considered primarily in relation to the person affected by this addiction and his/her relatives [1].

This article introduces the psychological and social conditions of work addiction and is an attempt to understand the essence of the phenomenon of 
workaholism.

\section{Methods}

The authors of the study, based on a review of the available literature, presented the topic of addiction to work and described the main determinants shaping workaholism and the so-called workaholic personality.

\section{Definitions and criteria for recognizing workaholism}

On starting the analysis of the phenomenon of workaholism, it is worth bearing in mind the main definition assumptions and criteria for recognizing work addiction. In most research studies, workaholism is recognized as a multidimensional phenomenon, including behavioral, cognitive and affective components [2,3,4]. Workaholism is often described as a pattern of excessive time spent at work, in excess of explicit and implied norms, as well as being quite absorbed in work [5]. Few questionnaires have been developed to assess the concept of workaholism, defined in terms of high scores in measuring work engagement and low scores in assessing job satisfaction [6]. The above definition assumptions are confirmed by studies [7].

The model proposed by Salomon captures workaholism as a type of addiction. According to this model, we can talk about work addiction when: (a) work causes a pleasant emotional state; (b) affective tolerance arises as a result of the need to increase portions of work; (c) there are signs of abstinence if work is prevented. The presented model points out that the compulsion to work causes positive emotion, satisfaction, which determines the strengthening of a specific type of behavior repertoire $[4,8]$.

Another concept of workaholism is presented by Seligman who believes that workaholism is a specific way of functioning of an employee due to his addiction to work [8]. One aspect of this specificity is strong commitment to work, which is a property positively evaluated by employers. Such an assessment, however, can only refer to the initial phase of the development of workaholism. If you look at this phenomenon in the long term, you should evaluate it negatively. Like any addiction, it leads to harmful effects for the individual and the organization employing it $[9,10]$.

Due to the difficulties in the unambiguous diagnosis of workaholism, criteria have been developed to identify addiction to work on the basis of the International Statistical Classification of Diseases and Health Problems ICD-10 [11]. It should be noted that the criteria that will be presented in the paper are analogical to the criteria of alcohol dependence and are not part of the ICD system [11]. These include a list of six symptoms related to compulsory work, of which at least three should be present over the past year as to recognize workaholism. The occurrence of a specific behavioral repertoire is not a consequence of an episode of hypomania or mania [11, 12]:

1. Compulsion - a person feels the compulsion to perform work and activities related to it;

2. Loss of control - experience of subjective loss of control over related behaviour with performing a specific job, a person has difficulty refraining from performing certain professional activities (no control over the amount of time spent on performing work);

3. Withdrawal symptoms - recurring anxiety, irritability, depressed mood appear when work is discontinued, when you return to performing certain professional activities these symptoms are significantly reduced or completely disappear;

4. Tolerance - a person feels the urge to increase the amount of work in order to reduce the emotional tension felt and to obtain contentment and satisfaction from the work performed;

5. Dominance of compulsive behaviour - alternative forms of pleasure that have been hitherto enjoyed are neglected in the interests of forced labor;

6. Negative consequences - a person continues certain related activities devoting a large amount of time to work despite potential negative physical, psychological and social consequences [12].

Taking into account various concepts and definition criteria of workaholism for the purposes of this article, the authors adopted the following definition of workaholism: it is a specific way of functioning of an employee resulting from work addiction, which includes compulsions, loss of control of work-related behaviours, occurrence of withdrawal symptoms, neglect of previous interests, devoting more and more time to work and ignoring its negative effects, i.e. physical and mental exhaustion [12].

\section{Workaholism as unashamed holism}

Workaholism seems to be a fairly common type of addiction. Work addiction is increasingly treated as one of the threats of the modern world, but also as one of the civilization diseases [13].

According to Płaczkiewicz, the situation of human work can be presented in a multidimensional way, taking into account economic, social, contextual and psychological aspects. Work is an unquestionable value, bringing comprehensive benefits to the individual. Treating things from a psychological perspective, it is worth mentioning such positive sides of work as an increase in self-esteem, the ability to meet many important needs, a sense of being "useful", developing psychosocial skills, especially communication $[14,15]$.

Paradoxically, the significance and role of work in human life can often be seen only when it is lost, which 
is exemplified in the status of the unemployed. There are also some risks to human health and psychological functioning, such as excessive and prolonged stress or burnout, associated with performing work. Therefore, maintaining the right balance between the time of performing professional duties and the time of rest, effective ways of coping with difficult situations or a "healthy" attitude towards work and professional role, seem necessary for maintaining mental hygiene and wellbeing [14].

In her work, Malinowska discusses the phenomenon of excessive work, which is one of the important social problems of the modern world. However, theoretical knowledge about this phenomenon, its mechanism and effects is still incomplete and disordered, which results from the fact that workaholism, as a psychological and social phenomenon is the object of very scarce empirical studies [12].

\section{Motivation to work - between passion and addiction}

Analyzing the factors conditioning the formation of workaholism, the role of motivation is worth mentioning. It is the process that induces action, and gives direction and is also an important factor supporting them to meet physical or mental needs and desires. Basically, we distinguish two types of motivation: (1) External motivation - leading to an external result, and (2) Internal motivation - thanks to which the action is undertaken because in its very essence, it is a gratification, reward, challenge or source of internal satisfaction for the subject [16]. It is worth noting here that pioneering attempts to understand motivation focused on the biologically conditioned connection between internal physiological states and external behavior. Homeostasis - i.e. the body's tendency to maintain equilibrium - is a part of this theory. The core of motivation are the needs: the need for achievements, belonging, power $[15,16]$. In this place it is worth asking the question: where does the strong need for achievement come from?

According to a researcher of motivation and personality - psychologist Carol Dweck, the need for achievements is closely related to personality factors shaping the image of oneself [16]. A specific way of receiving "self" by an entity can influence the way of giving specific meaning to one's own action in order to achieve success [16]. This concept is associated with a much older concept of a sense of localization of control, according to which persons who assume that they have power over their lives are considered to have internally located control, while persons who have the impression that their lives are controlled by stronger external factors such as : 'luck' or 'blind fate' - they are considered to have externally located control. People's theories about their own "self" can affect their level of motivation for achievement and their willingness to make further attempts to succeed despite defeat [16].

In addition, a stimulation-based approach is distinguished, which assumes that the motivational stimulus gives the impression of being unlearned, but it causes an increase in arousal; In turn, the approach based on excitement, explains behavior through external stimuli and their rewarding features. The humanistic approach assumes that the achieved goal for the subject is selfrealization, identified with the release of the full potential. Workaholic is addicted to the award [17]. It is the reward and the associated feeling of pleasure that motivate to act and encourage to maintain the adaptive reaction. Feeling pleasure is possible due to the secretion of large amounts of dopamine into the nucleus accumbens dopamine affects the motivation to look for strengthening the stimuli. Pathology begins when dopamine is secreted in excessive amounts, which leads to tolerance, so more dopamine is required to achieve the desired effect. Workaholic is working more and more, setting himself more and more tasks to feel pleasure [17].

\section{Workaholic personality - does it really exist?}

According to Wojdyło, who adopts the concept of workaholic personality, such personality is characterized by internal pressure of work and its overload [18]. For workaholics, a high level of external motivation is characteristic (focus on achievements and the need for social approval in terms of fitness traits) and high motivation for avoiding failure (orientation on avoidance) [17]. It is about the mechanism of work obsession, which is visible in the average energy expenditure at work, overstatement of task performance standards, a certain repetition of actions and the inability to "turn off". Negative emotions lined with fear and the so-called stimulating stimulation. Other significant factors in shaping and consolidating work addiction are low emotional self-determination (AUTEM) and high intellectual self-determination (AUTIN) $[18,19]$.

An analysis of the literature indicates that workaholics - due to the high motivation to avoid failure, but also external motivation - will be different from those, let us assume, non-workaholics in a task-related achievement situation. In the conducted experiment, it was checked whether the dimensions of behaviour related to achievements such as: level of aspiration, perseverance and level of own achievements were shaped by three factors: level of difficulty, complexity of the task, feedback on the result achieved and a certain workaholism syndrome. Sixty workaholics and sixty non-workaholics performed the SYZYF computer task, which required eyehand coordination [18]. 
The level of anxiety-state and anxiety-trait were measured in these subjects. Workaholics had a higher level of anxiety-state and anxiety-trait than non-workaholics. People addicted to work showed a higher level of aspiration, worked comparatively persistently and did not differ significantly from non-working people in terms of achievement. Obtained data confirm to a certain degree, the thesis about the relationship between workaholism and the motivation to avoid failure. The results also suggest that the motivation to avoid failure in people addicted to work is probably compensated by external motivation - accomplishments [16,18,19]. Golińska studied workaholism in the context of political and economic changes that had a great impact on the consciousness and functioning of people. A more important change is the increase in self-esteem [20].

Good professional and economic position depends on competence, commitment, while professional success is a matter of qualification, determination and talent. Work creates new opportunities, both in the objective aspect (position, earnings) and in subjective perception: it confirms the sense of self-efficacy, builds trust to their skills and capabilities, satisfies the need for recognition or power. Competence and efficiency at work, promote selffulfilment, so work becomes a particularly attractive way to confirm their value $[1,20]$. Man's relations with work are defined in three dimensions, i.e. : work involvement, forced work (feeling driven to work) and work satisfaction (enjoyment of work) [4,6]. Different frames of these dimensions build up the employee type. Workaholics are very absorbed at work, they feel compelled to do it, but do not feel this satisfaction $[20,21]$. On the other hand, work enthusiasts are preoccupied with work, experience satisfaction during it, but do not feel internal pressure on it [20].

\section{Results and conclusions}

This study presents the author's theoretical proposition of the notion of workaholism which postulates the existence of a form of addiction to work, which has its source in workaholic personality. Motivation to work plays an important role in this context, so various approaches have been presented. Undoubtedly, workaholism is addictive, but obsessive-compulsive components alone may not be sufficient to determine its nature. Workaholism is characterized by a three-dimensional structure, which includes behavioral, cognitive and affective dimensions, what allows the integration of different perspectives and confirms the existence of dysfunctional and functional types of workaholics [22,23]. Further research on this issue is definitely necessary.
"Ludzie spieszq się $w$ pracy, dlatego niedbale ja wykonuja; spieszq sie $w$ używaniu życia, dlatego jego smaku nie odczuwają; spiesza się w odpoczynku, dlatego nie mogą wypocząć."

\section{A. Kępiński Rytm życia}

\section{Wprowadzenie i cel pracy}

Współczesny świat narzuca pewien egzystencjalny pośpiech, w dobie informatyzacji, innowacji i coraz nowszych udogodnień, wszechobecna jest tendencja do pogoni za sukcesem, a na tym gruncie może rodzi się pracoholizm. Zjawiskiem pracoholizmu zajmują się głównie psycholodzy, zaś jego konsekwencje rozpatrywane są przede wszystkim $\mathrm{w}$ odniesieniu do osoby dotkniętej tym uzależnieniem oraz jej bliskich [1].

Niniejszy artykuł przybliża psychologiczne i społeczne uwarunkowania uzależnienia od pracy oraz jest próbą zrozumienia istoty fenomenu uzależnienia od pracy.

\section{Metodyka pracy}

Autorzy pracy na podstawie przeglądu dostępnego piśmiennictwa przedstawili tematykę uzależnienia od pracy i opisali główne determinanty kształtujące pracoholizm i tzw. osobowość pracoholiczną.

\section{Definicje i kryteria rozpoznawania pracoholizmu}

Przystępując do analizy zjawiska pracoholizmu warto mieć na uwadze główne założenia definicyjne oraz kryteria rozpoznawania uzależnienia od pracy. W większości prac badawczych pracoholizm ujmowany jest jako zjawisko wielowymiarowe, obejmujące komponenty behawioralne, poznawcze i afektywne $[2,3,4]$. Pracoholizm jest często opisywany jako wzorzec nadmiernego czasu spędzanego w pracy, w ilości większej niż wyraźne i domniemane normy, a także jako znaczne zaabsorbowanie pracą [5]. Opracowano nieliczne kwestionariusze celem oceny koncepcji pracoholizmu, zdefiniowanej w kategoriach wysokich wyników w pomiarach zaangażowania w pracę i niskich wyników w ocenie stopnia zadowolenia z pracy [6]. Powyższe założenia definicyjne potwierdzają badania [7].

Model zaproponowany przez Salomona ujmuje pracoholizm jako rodzaj uzależnienia. Zgodnie z tym modelem o uzależnieniu od pracy możemy mówić wtedy, 
gdy: (a) praca wywołuje przyjemny stan emocjonalny; (b) powstaje tolerancja afektywna przejawiająca się koniecznością zwiększania porcji pracy; (c) występują objawy abstynencji w przypadku uniemożliwienia wykonywania pracy. Zaprezentowany model zwraca uwagę, że przymus pracy powoduje emocję pozytywną, zadowolenie, co warunkuje wzmocnienie określonego typu repertuaru zachowań $[4,8]$.

Inną koncepcję pracoholizmu przedstawia Seligman, który uważa, że pracoholizm jest specyficznym sposobem funkcjonowania pracownika spowodowanym jego uzależnieniem od pracy [8]. Jednym z aspektów tej specyfiki jest silne zaangażowanie w pracę, co jest właściwością pozytywnie ocenianą przez pracodawców. Taka ocena może jednak odnosić się tylko do wstępnej fazy rozwoju pracoholizmu. Jeśli patrzy się na to zjawisko w długiej perspektywie, należy je oceniać negatywnie. Jak każde bowiem uzależnienie prowadzi do skutków szkodliwych dla jednostki i zatrudniającej ją organizacji $[9,10]$.

Ze względu na trudności w jednoznacznym rozpoznaniu pracoholizmu opracowano kryteria umożliwiające rozpoznanie uzależnienia od pracy na podstawie Międzynarodowej Statystycznej Klasyfikacji Chorób i Problemów Zdrowotnych ICD-10 [11]. Należy zaznaczyć, że kryteria, które zostaną przedstawione w pracy, stanowią analogię do kryteriów uzależnienia od alkoholu i nie są elementem systemu ICD [11]. Obejmują one listę sześciu objawów związanych z przymusem wykonywania pracy, spośród których co najmniej trzy powinny występować u danej osoby w ciągu ostatniego roku, żeby rozpoznać u niej pracoholizm. Występowanie określonego repertuaru zachowań nie jest następstwem epizodu hipomanii lub manii $[11,12]$ :

1. Kompulsja - osoba odczuwa przymus wykony wania pracy oraz czynności z nią związanych;

2. Utrata kontroli - doświadczenie subiektywnej utraty kontroli zachowań związanych z wykonywaniem określonej pracy, osoba ma trudności $\mathrm{z}$ powstrzymaniem się od pełnienia określonych czynności zawodowych (brak kontroli nad ilością czasu poświęcanego na wykonywanie pracy);

3. Objawy odstawienia - w przypadku przerwania pracy pojawiają się nawracające stany niepokoju, rozdrażnienia, obniżenia nastroju, w momencie powrotu do wykonywania określonych czynności zawodowych objawy te ulegają znaczącej redukcji lub ustępują całkowicie;

4. Tolerancja - osoba odczuwa przymus zwiększania ilości pracy $\mathrm{w}$ celu redukcji odczuwanego napięcia emocjonalnego oraz uzyskania zadowolenia i satysfakcji z wykonywanej pracy;
5. Dominacja nałogowej formy zachowania alternatywne formy zachowania sprawujące dotychczas przyjemność zostają zaniedbywane na rzecz przymusu wykonywania pracy;

6. Negatywne konsekwencje - osoba kontynuuje określone czynności związane z poświęcaniem dużej ilości czasu na pracę pomimo potencjalnych możliwych negatywnych następstw fizycznych, psychicznych i społecznych [12].

Biorąc pod uwagę różne koncepcje oraz kryteria definicyjne pracoholizmu na potrzeby niniejszego artykułu autorzy przyjęli następującą definicję pracoholizmu: jest to określony sposób funkcjonowania pracownika będący skutkiem uzależnienia od pracy, który obejmuje kompulsje, utratę kontroli zachowań związanych z pracą, występowanie objawów odstawienia, zaniedbywanie dotychczasowych zainteresowań, poświęcanie pracy coraz większej ilości czasu oraz ignorowanie jej negatywnych skutków tj. wyczerpanie fizyczne i psychiczne [12].

\section{Pracoholizm niewstydliwym holizmem}

Pracoholizm wydaje się dość rozpowszechnionym typem uzależnienia. Uzależnienie od pracy jest coraz częściej traktowane jako jedno z zagrożeń świata współczesnego, ale też jedna z chorób cywilizacyjnych [13].

Zdaniem Płaczkiewicz sytuację pracy ludzkiej można ujmować w sposób wielowymiarowy, z uwzględnieniem aspektów ekonomicznych, społecznych, kontekstualnych, psychologicznych. Praca stanowi niepodważalną wartość, przynosząc wszechstronne korzyści dla jednostki. Traktując rzecz z perspektywy psychologii, warto wspomnieć o takich dodatnich stronach pracy, jak wzrost poczucia własnej wartości, możliwość realizacji wielu ważnych potrzeb, poczucie bycia „użytecznym”, rozwijanie umiejętności psychospołecznych, szczególnie komunikacyjnych [14,15].

Paradoksalnie o znaczeniu i roli pracy w życiu człowieka niejednokrotnie przekonać się można dopiero w sytuacji jej utraty i uzyskania statusu osoby bezrobotnej. Z wykonywaniem pracy wiążą się też pewne zagrożenia dla zdrowia i funkcjonowania psychologicznego człowieka, jak nadmierny i długotrwały stres czy wypalenie zawodowe. A zatem zachowanie właściwych proporcji między czasem wykonywania obowiązków zawodowych i czasem odpoczynku, efektywne sposoby radzenia sobie w sytuacjach trudnych czy „zdrowa” postawa wobec pracy i roli zawodowej, wydają się niezbędne dla zachowania higieny psychicznej i dobrego samopoczucia [14].

Malinowska w swej pracy omawia zjawisko nadmiernej pracy, które należy do ważnych społecznych 
problemów współczesnego świata. Wiedza teoretyczna o tym zjawisku, mechanizmie jego powstawania i skutkach jest jednak nadal niepełna i nieuporządkowana, co wynika z tego, że pracoholizm jako zjawisko psychologiczne i społeczne jest obiektem niewielu badań empirycznych [12].

\section{Motywacja do pracy - między pasją a uzależnieniem}

Analizując czynniki warunkujące powstawanie pracoholizmu warto przytoczyć rolę motywacji. To ona jest procesem indukującym działanie, oraz nadaje kierunek a także stanowi ważny czynniki podtrzymujący je w celu zaspokojenia fizycznych lub psychicznych potrzeb i pragnień. Zasadniczo wyróżniamy dwa rodzaje motywacji: (1) Motywacja zewnętrzna - prowadząca do zewnętrznego rezultatu i (2) Motywacja wewnętrzna - dzięki której działanie jest podejmowane, ponieważ samo w sobie stanowi gratyfikacje, nagrodę, wyzwanie lub źródło wewnętrznej satysfakcji dla podmiotu [16]. W tym miejscu warto zaznaczyć, że pionierskie próby zrozumienia motywacji koncentrowały się na biologicznie uwarunkowanym powiązaniu pomiędzy wewnętrznymi stanami fizjologicznymi a zewnętrznym zachowaniem. Elementem owej teorii jest homeostaza - tj. tendencja organizmu do utrzymywania stanu równowagi. Sednem motywacji są potrzeby: potrzeba osiągnięć, przynależności, władzy $[15,16]$. W miejscu tym warto postawić pytanie: skąd bierze się u ludzi silna potrzeba osiągnię?

Według badaczki motywacji i osobowości - psycholog Carol Dweck potrzeba osiągnięć ma bliski związek z czynnikami osobowościowym kształtującymi obraz własnej osoby [16]. Określony sposób obioru "self" przed podmiot może wpłynąć na sposób nadawania określonego znaczenia własnemu działaniu w celu osiągnięcia sukcesu [16]. Koncepcja ta jest powiązana ze znacznie starszym pojęciem poczucia umiejscowienia kontroli, w myśl którego osoby, które zakładają, że sprawują władzę nad swoim życiem uważa się za posiadające wewnętrznie umiejscowioną kontrolę, natomiast osoby odnoszące wrażenie, że ich życiem sterują silniejsze od nich czynniki zewnętrzne takie jak: szczęście bądź ślepy los - uważane są za posiadające zewnętrznie umiejscowioną kontrolę. Teorie ludzi dotyczące ich własnego „self” mogą wpływać na poziom ich motywacji do osiągnięć oraz gotowość do podejmowania kolejnych prób osiągnięcia sukcesu mimo doznanej klęski [16].

Oprócz tego wyróżniono podejście oparte na pobudzeniu, które zakłada, że bodziec motywujący stwarza wrażenie niewyuczonego, lecz wywołuje wzrost pobudzenia; Natomiast podejście oparte na podnietach, tłumaczy zachowanie poprzez zewnętrzne bodźce oraz ich cechy nagradzające. Podejście humanistyczne, zakłada, że osiąganym celem dla podmiotu jest samorealizacja, utożsamiana z wyzwoleniem pełni własnego potencjału. Pracoholik uzależniony jest od nagrody [17]. To właśnie nagroda i związane z nią odczuwanie przyjemności ma motywować do działania i zachęcać do podtrzymywania reakcji adaptacyjnej. Odczuwanie przyjemności możliwe jest dzięki wydzielaniu dużych ilości dopaminy do jądra półleżącego (nucleus accumbens). Dopamina wpływa na motywację do poszukiwania bodźców wzmacniających. Patologia rozpoczyna się, gdy dopamina wydzielana jest w zbyt dużych ilościach, co prowadzi do tolerancji, a więc wymagana jest większa ilość dopaminy w celu osiągnięcia pożądanego efektu. Pracoholik pracuje coraz więcej, stawia sobie coraz większe wymagania, aby odczuć przyjemność [17].

\section{Osobowość pracoholiczna - czy istnieje naprawdę?}

Według Wojdyło podejmującej koncepcję osobowości pracoholicznej, osobowość taką cechuje wewnętrzny przymus pracy oraz przeciążenie nią [18]. Dla pracoholików charakterystyczny jest wysoki poziom motywacji zewnętrznej (ukierunkowanie na dokonania i potrzeba społecznej aprobaty w zakresie cech sprawnościowych) oraz wysoka motywacja względem unikania niepowodzenia (orientacja na unikanie) [17]. Chodzi tu o mechanizm obsesji pracy, uwidaczniający się $\mathrm{w}$ ponadprzeciętnym wydatkowaniu energii w pracy, zawyżaniu standardów wykonania zadania, pewnej powtarzalności działania i braku możności „wyłączenia się”. Ważną rolę pełnią także negatywne emocje podszyte lękiem oraz tzw. pobudzenie mobilizujące. Innymi znaczącymi czynnikami w kształtowaniu i utrwalaniu się uzależnienia od pracy jest niska autodeterminacja emocjonalna (AUTEM), a wysoka — intelektualna (AUTIN) $[18,19]$.

Analiza piśmiennictwa wskazuje, że pracoholicy w związku z wysoką motywacją unikania niepowodzenia, ale i motywacją zewnętrzną - będą różnić się od tych, przyjmijmy, niepracoholików w sytuacji zadaniowej związanej $\mathrm{z}$ osiągnięciami. W przeprowadzonym eksperymencie sprawdzano, czy wymiary zachowania wiążące się z osiągnięciami takimi jak: poziom aspiracji, wytrwałość i poziom własnych osiągnięć, kształtowane są przez trzy czynniki: poziom trudności, zawiłości zadania, informacje zwrotne o wyniku osiągniętym oraz niejaki syndrom pracoholizmu. Sześćdziesięciu pracoholików i sześćdziesięciu niepracoholików wykonywało komputerowe zadanie SYZYF, wymagające koordynacji wzrokowo-ruchowej [18].

U tychże badanych dokonano pomiaru poziom lękustanu oraz lęku-cechy. Pracoholików cechował wyższy aniżeli niepracoholików poziom lęku-stanu i lękucechy. Osoby uzależnione od pracy przejawiały wyższy 
poziom aspiracji, pracowały porównywalnie wytrwale i nie różniły się istotnie od niepracoholików pod kątem osiągnięć. Uzyskane dane potwierdzają, oczywiście do określonego stopnia, tezę o związku pracoholizmu z motywacją unikania niepowodzenia. Rezultaty sugerują też, że motywacja do unikania niepowodzenia u osób uzależnionych od pracy jest prawdopodobnie kompensowana przez motywację zewnętrzną - dokonań $[16,18,19]$. Golińska przebadała pracoholizm w kontekście zmian ustrojowo-ekonomicznych, jakie wpłynęły bardzo na świadomość i sposób funkcjonowania ludzi. Ważniejszą zmianą stanowi wzrost poczucia własnej sprawczości [20].

Dobra pozycja zawodowa i ekonomiczna uzależniona jest od kompetencji, zaangażowania, sukces zawodowy zaś jest kwestią kwalifikacji, determinacji oraz talentu. Praca bowiem rodzi nowe, możliwości, zarówno w aspekcie obiektywnym (pozycja, zarobki), jak i w odbiorze subiektywnym: potwierdza poczucie samoskuteczności, buduje zaufanie do swoich umiejętności, tudzież możliwości, zaspokaja potrzebę uznania czy władzy. Kompetencja oraz efektywność w pracy sprzyja samorealizacji toteż praca staje się szczególnie atrakcyjnym sposobem, aby potwierdzić swoją wartość $[1,20]$. Relacje człowieka z pracą określają trzy wymiary tj.: zaabsorbowanie pracą (work involvement), przymus pracy (feeling driven to work) oraz zadowolenie z pracy (enjoyment of work) [4,6]. Różne kompilacje tych wymiarów konstruują typ pracownika. Pracoholicy są bardzo pochłonięci pracą, odczuwają przymus jej wykonywania, lecz nie odczuwają owego zadowolenia $[20,21]$. Entuzjaści pracy są natomiast zaabsorbowani pracą, doświadczają zadowolenia w jej trakcie, ale nie odczuwają wewnętrznej presji na jej wykonywanie [20].

\section{Podsumowanie i wnioski}

W niniejszej pracy przedstawiono autorską propozycję teoretyczną pracoholizmu, która postuluje istnienie formy uzależnienia od pracy, mającej swoje źródło w osobowości pracoholicznej. Ważną rolę odgrywa w tym kontekście motywacja do pracy, toteż zaprezentowano różnorakie podejścia. Niewątpliwie pracoholizm ma charakter uzależnienia, lecz same komponenty obsesyjno-kompulsyjne mogą okazać się niewystarczające do określenia jego natury. Pracoholizm cechuje struktura trójwymiarowa, która obejmuje wymiary behawioralne, poznawcze i afektywne, co umożliwia integrację różnych perspektyw i potwierdza istnienie dysfunkcyjnych oraz funkcjonalnych rodzajów pracoholików [22,23]. Niezbędne są dalsze badania tego zagadnienia.

\section{Conflict of interest}

The authors have declared no conflict of interest.

\section{References}

1. Lipka A., Pracoholizm w ujęciu ekonomii behawioralnej i tradycyjnej. Studia Ekonomiczne, 2013; (148), 9-28.

2. Robinson B.E., A typology of workaholics with impilcations for counselors. J. Addict. Offender.Couns. 2000; 21 (1):34 - 48.

3. Golińska L., Skala do badania zaabsorbowania pracą (SZAP) Acta Universitatis Lodziensis. Folia Psychol., 2005; 9:17 - 29.

4. Dudek B., Pracoholizm - szkodliwy skutek nadmiernego zzangażowania w pracę. Medycyna pracy, 2008; 59 (3): 247-254.

5. Andreassen C.S., Griffiths M.D., Hetland J., Pallesen S. Development of a work addiction scale. Scandinavian journal of psychology, 2012; 53(3), 265-272.

6. Spence J.T., Robbins A.S., Workaholism; definition, measurement and preliminary results. J. Pers. Assess., 1992; 58 (1):160 - 178.

7. Ersoy-Kart M., Reliability and validity oft he Workaholism Battery (Work-Bat). Turkish form. Soc. Behav. Pers., 2005; 33 (6):609- 618 .

8. Paluchowski W.J., Hornowska E., Pracoholizm a system wartości i uwarunkowania temperamentalne. W: Witkowski S. [red]. Psychologiczne wyznaczniki sukcesu w zarządzaniu, Wydawnictwo Uniwersytetu Wrocławskiego, Wrocław, 2003, s. 297-321.

9. Ostrowska M., Michcik A., Pracoholizm-przyczyny, konsekwencje, przeciwdziałanie. Bezpieczeństwo Pracy: nauka i praktyka, 2014; 10-13.

10. Szostek D., Badania sondażowe opinii $\mathrm{w}$ procesie identyfikowania pracoholizmu w organizacji. Handel Wewnętrzny, 2016; 361(2), 396-409.

11. Woronowicz B.T., Uzależnienia: geneza, terapia, powrót do zdrowia. Media Rodzina. Poznań, 2009.

12. Malinowska D.,Staszczyk S., Tokarz A., Pracoholizm - wskazania dotyczące diagnozy oraz przegląd działan interwencyjnych. Medycyna Pracy, 2015; 66 (1):71 - 83.

13. Atroszko P., Atroszko B., Uzależnienie od uczenia sięrozpowszechnienie zjawiska oraz potencjalne oddziaływania terapeutyczne i profilaktyczne, 2015.

14. Płaczkiewicz B., Psychologiczne aspekty funkcjonowania człowieka w sytuacji pracy. Artykuły i rozprawy. 2016; 65-75.

15. Pluta A., Wydłużający się czas pracy-zjawisko czy trend? Ekonomika i Organizacja Przedsiębiorstwa, 2011; 6: 41-50.

16. 16. Ciccarelli S.K., White J.N., Domachowski W., Bukowski A., Środa J.,. Psychologia. Dom Wydawniczy Rebis, 2015; 342-375.

17. Szpitalak M., Przywiązani... do pracy. Zaangażowanie w pracę jako odzwierciedlenie stylu przywiązania, Psychologia Rozwojowa, 2010; 15(2).

18. Wojdyło K. Osobowość pracoholiczna: właściwości i mechanizmy regulacyjne. Nowiny Psychologiczne, 2006; 2: 23 36.

19. Wojdyło K. Funkcjonowanie pracoholików w sytuacji zadaniowej. Przegląd psychologiczny, 2010; 53(1): 75-98.

20. Golińska L., Pracoholizm - istota, konsekwencje i uwarunkowania. Acta Universitatis Lodziensis. Folia Psychologica. 2010; (14): 97-107.

21. Wojdyło K., Lewandowska-Walter A., Kontrola działania u osób uzależnionych od pracy. Przegląd Psychologiczny, 2009; 52(4).

22. Malinowska D., Tokarz A., Gad N., Wstępne badania nad adaptacją skali Workaholism Battery (WorkBAT) Spence i Robbins. Studia Psychologiczne, 2010; 48(3).

23. Malinowska D., Tokarz A. The structure of workaholism and types of workaholic. Polish Psychological Bulletin, 2014. 


\section{Corresponding author}

Aleksandra Iwanicka

II Klinika Psychiatrii i Rehabilitacji

Psychiatrycznej Katedry Psychiatrii Uniwersytetu

Medycznego w Lublinie

Otrzymano:06.04.2020

Zrecenzowano:22.04.2020, 18.05.2020

iwanicka.aleksandra123@gmail.com

Przyjęto do druku:22.05.2020 